\title{
Salivary levels of SIgA and perceived stress among dental students
}

\section{Imunoglobulina A salivar e fatores de estresse em estudantes de odontologia}

João Paulo Menck Sangiorgio ${ }^{1}$ (orcid.org/0000-0001-7201-9366), Gabriela Fleury Seixas ${ }^{2}$ (orcid.org/0000-0002-27390307), Solange de Paula Ramos ${ }^{3}$ (orcid.org/0000-0002-8296-7770), Cássia Cilene Dezan-Garbelini (orcid.org/0000-00028660-0677)

1. Instituto Federal do Paraná (IFPR), Londrina, PR, Brasil. 2. Discente de Pós-graduação em Odontologia pela Universidade Norte do Paraná (UNOPAR), Londrina, PR, Brasil. 3. Docente pela Universidade Estadual de Londrina (UEL), Londrina, PR, Brasil

\begin{abstract}
Background: Academic stress may impair mucosal immunity and expose dental students to an increased risk of infections. Objective: to assess stress scores in dental students and their relationship with variation in SIgA levels. Methods: All students $(\mathrm{n}=289)$ were invited to take part of the study, and 207 (71.63\%) effectively participated, being 152 (73.4\%) females. At the day of data collection, the students answered The Dental Environmental Stress Questionnaire (DES) and unstimulated saliva samples were collected for determination of salivary flow rate and SIgA concentration and secretion rate. Results: Mean DES scores were higher in females (78.97 \pm 16.42$)$, but no correlations between the sum of DES scores and salivary parameters were observed $(\mathrm{P}=0.08)$. A moderate inverse relationship was observed between SIgA secretion rates and the subscales Academic Performance ( $\mathrm{P}=0.01)$, Interpersonal relationships $(\mathrm{P}=0.02)$ and Difficulties and Insecurities about Professional Future $(\mathrm{P}=0.05)$. A weak correlation was found between SIgA concentration and the items Amount of assigned classwork $(\mathrm{P}=0.02)$, Lack of confidence in self to be a successful dentist $(\mathrm{P}=0.01)$, Lack of time for relaxation $(\mathrm{P}=0.01)$, Financial responsibilities $(\mathrm{P}=0.02)$ and Personal physical health $(\mathrm{P}=0.005)$. Weak correlations between SIgA secretion rates and DES items were also found for Lack of cooperation by patient in their home care $(\mathrm{P}=0.003)$, Patients being late or not showing up for their appointments ( $\mathrm{P}=0.02)$, Lack of self confidence to be a successful dentist $(\mathrm{P}=0.008)$, Personal physical health $(\mathrm{P}=0.019)$, and others. Conclusion: Different sources of stress were observed among first to fifth year students and some of these stressors may negatively impact on salivary SIgA secretion.
\end{abstract}

Key words: Mucosal immunity. Dental student. Stress

\section{Resumo}

Introdução: o estresse acadêmico pode prejudicar a imunidade das mucosas e expor os estudantes de odontologia a um maior risco de infecções. Este estudo teve como objetivo avaliar os fatores de estresse em estudantes de odontologia e sua relação com a variação nos níveis de SIgA. Metodologia: Todos os alunos $(\mathrm{n}=289)$ foram convidados a fazer parte do estudo, dos quais $207(71,63 \%)$ participaram efetivamente, sendo 152 $(73,4 \%)$ do sexo feminino. No dia da coleta de dados, os alunos responderam ao Questionário de Estresse no Ambiente Odontológico (DES) e foram coletadas amostras de saliva não estimuladas para determinação da taxa de fluxo salivar, da concentração de SIgA e da taxa de secreção. Resultados: os escores do DES foram maiores no gênero feminino $(78,97 \pm 16,42)$, mas não foram observadas correlações entre a soma dos escores DES e os parâmetros salivares $(P=0,08)$. Observou-se uma relação inversa moderada entre as taxas de secreção de SIgA e as subescalas Desempenho Acadêmico $(\mathrm{P}=0,01)$, Relações Interpessoais $(\mathrm{P}=0,02)$ e Insegurança em relação ao futuro profissional $(P=0,05)$. Uma correlação fraca foi encontrada entre a concentração de SIgA e os itens quantidade de trabalho exigido em sala de aula $(\mathrm{P}=0,02)$, falta de autoconfiança para ser um dentista de sucesso $(\mathrm{P}=0,01)$, falta de tempo para relaxar ou para lazer $(\mathrm{P}=$ $0,01)$, responsabilidades financeiras $(P=0,02)$ e saúde física pessoal $(P=0,005)$. Também foram encontradas correlações fracas entre as taxas de secreção de SIgA e os itens DES para falta de cooperação por parte do paciente em seus cuidados $(\mathrm{P}=0,003)$, Atraso ou falta de pacientes nas consultas $(\mathrm{P}=0,02)$, falta de autoconfiança para ser um dentista bem sucedido $(P=0,008)$, saúde física pessoal $(P=0,019)$ e outros. Conclusão: diferentes fontes de estresse foram observadas entre os estudantes do primeiro ao quinto ano e alguns desses fatores podem afetar negativamente a secreção de SIgA.

Palavras-chave: Imunidade. Estudante odontológico. Estresse.

\section{INTRODUCTION}

Undergraduate students experience psychosocial stress involving exams, mental burnout, employment expectancy and others ${ }^{1,2}$. Besides the stressors commonly reported by undergraduate students, dental students also face the pressure to develop clinical competencies and interpersonal skills; all within a short period of time, in order to become a responsible dental professional ${ }^{3-6}$. These include unfavorable physical positions, noise, repetitive movements, high professional competitiveness, heavy course work and lack of time for relaxation and interaction with friends and family ${ }^{3-8}$. All these factors may contribute to make the undergraduates feel insecure, stressed, anxious, depressed and sometimes even display suicidal intentions ${ }^{7,8}$. Such stressors may have an important impact on oral immunity since salivary secretion and immune functions are controlled by stress-modulated systems such as the endocrine and nervous systems ${ }^{1,2}$.

Correspondence: João Paulo Menck Sangiorgio, Department of Oral Medicine and Dentistry for Children, Dentistry. State University of Londrina, Brazil. Phone/fax; +55 4333716700; joao.sangiorgio@gmail.com

Conflict of interest: The authors declare that they have no conflicting interests.

Received: 4 Jul 2017; Revised: 16 Set 2017;25 Out 2017; Accepted: 30 out 2017 
There are several reports about perceived stressors in dental students, ${ }^{3,5,6,9-12}$ but there is a lack of studies devoted to investigate how perceived stress influences oral immunity ${ }^{13}$. Salivary secretory $\lg A(S \lg A$ ) is an antibody secreted by acinar cells in salivary glands and this is one of the most important lines of defense of the oral cavity and upper respiratory tract $^{14}$. SIgA secretion can have downmodulation occasioned by psychosocial and physical stress ${ }^{2,15}$. During acute stress, an increase in SIgA levels can be detected ${ }^{16}$; on the other hand, chronic stress may negatively impact on SIgA secretion ${ }^{17}$. Impairment in SIgA secretion may be caused by chronic cortisol release, triggered by mental and physical chronic stress, which suppresses secretory immunity; in summary, an increase in cortisol is significantly correlated with impaired SIgA secretion ${ }^{18}$. Additionally, low parasympathetic stimulation, which has been associated with anxiety and stress ${ }^{19}$, also negatively impacts on SIgA secretion due to the impaired transepithelial transport of the Poly-Ig receptor (a transport receptor for secretory antibodies) by acinar cells in salivary glands ${ }^{18,20}$.

Stress impacts on an individual's health and quality of life, influencing their professional, physical, psychological and social activities $^{21}$. A survey of undergraduate students observed that an acute psychological stressor, such as a job interview, could impair the secretion of salivary SIgA during recovery after the interview ${ }^{2}$. The role of acute stress (exams) on oral immunity among health science students is contradictory. Increased levels of SIgA immediately after an examination were described for nursing ${ }^{16,22}$, physiotherapy ${ }^{22}$, and medical students ${ }^{15}$. With regard to dental students, available reports point to no significant differences between salivary SIgA pre-and postexams $^{13}$. A similar finding was reported among undergraduate students attending Biology and introduction to Psychology courses $^{23}$.

Several studies in different countries, such as the U.K., Australia, Greece, India, Spain and Germany, reported on occupational stress in dental undergraduates and found that the factors affecting clinical students resemble those of qualified practitioner dental students ${ }^{3,5,6,9-12}$. Stress in dental students can cause depressive symptomatology, anxiety, behavior disorders, substance abuse, school dropout and decreased student performance. It may also lead to decreased attention, reducing concentration and patient-dentist relationship skills ${ }^{24}$. The instrument that is regularly used to identify perceived stressors among dental students is the Dental Environmental Stress questionnaire (DES) that was designed specifically for use in dental students ${ }^{25}$. This questionnaire has been recently validated for Portuguese, in order to provide information on the psychosocial status of Brazilian dental students ${ }^{26}$.

The reported high levels of perceived stress among dental students may compromise their oral immunity, which can be expressed through SIgA secretion in the mouth. This can lead to a negative impact on student's health and academic performance. The aim of this study was to investigate the correlation between oral immune functioning and self-reported measures of stress among undergraduate dental students.

\section{MATERIAL AND METHODS}

\section{Subjects}

This study received approval from the Ethics Committee for Research Involving Human Beings/UEL, CEP 252/2011. Data collection was carried out in a single Brazilian Public Dental School, in the beginning of the 2nd semester (August, winter time). This dental school encompasses a five-year study program, which has been in operation since 2005. It follows a traditional lecture-based system, with some modifications based on the Brazilian curriculum guideline,27 which aims to graduate a generalist, humanist, critical and participative professional.

The study objectives were explained to the students and all were invited to participate voluntarily ( $N=289$ ) with no sample size calculation since all the students were invited to participate. To be included in the study, the students were required to present good health (no self-reported disease at the time of the study) and oral health status (no caries, periodontal disease or oral lesions), not having flu, rhinitis or a common cold, and provide enough volume of salivary sample for analysis.

\section{DES}

All participants anonymously completed the DES. The instrument had been previously cross-culturally adapted to Portuguese (Brazilian version) and statistical analyses indicated the existence of 5 subscales among Brazilian students, with a numerical score to each item; higher scores indicate higher levels of stress26. The subscales comprised the following items:

I. Academic Performance - Amount of assigned classwork, Difficulty of classwork, Examinations and grades, Atmosphere created by faculty, Receiving criticism about work, Lack of time for relaxation and recreation, Completing graduation requirements, Reconciling personal life issues with dental school routines, Fear of failing course or year and Lack of time to do assigned school work.

II. Difficulties and Insecurities about Professional Future: Difficulty in learning clinical procedures; Difficulty in learning precision manual skills required in pre-clinical and laboratory work; Lack of confidence in self to be a successful dentalstudent; Lack of confidence in self to be a successful dentist; Insecurity concerning professional future and Fear of being unable to catch up if get behind.

III. Responsibilities with Patients: Lack of cooperation by patient in their home care; Responsibilities for comprehensive patient care; Patients being late or not showing up for their appointments and Working on patients with dirty mouths.

IV. Individual and Institutional Factors: Rules and regulations of the school; Expectations of dental school and what it is like in reality; Lack of participation in the school's decision-making; Financial responsibilities; Considering entering some other field of work; Difficulty in undertaking conjugal commitments; Personal physical health and Inconsistency of feedback on school-work among different instructors.

V. Interpersonal relationships: Competition for grades; 
Relations with members of the opposite sex; Amount of cheating in dental school; Lack of family atmosphere in the dormitories during school; Attitude of school toward female dental students; Conflict with the family throughout career development; Discrimination due to race, class status or ethnic group; and Attitude of school toward homosexual dental students.

\section{Salivary SIgA}

In order to avoid any physiological factor that could affect salivary flow rate and SIgA secretion rate, the samples were collected at the same time and day of the week between $10 \mathrm{am}$ and $12 \mathrm{pm}$. The samples were collected at rest, in the classrooms. Unstimulated whole saliva samples were collected after individuals had rinsed their mouth twice with water. Participants were instructed to spit any saliva they produced, for a period of $5 \mathrm{~min}$, into sterile tubes. No protease inhibitor was used in the sample before collection. Saliva samples were centrifuged at $12,000 \mathrm{rpm}$ for $10 \mathrm{~min}$ and then the supernatants were stored at -20 oC until analysis. Salivary flow rate was determined in $\mathrm{ml}$ of saliva secreted per $\min (\mathrm{ml} / \mathrm{min})$.

Salivary SIgA concentrations were determined using microtiter plates (Costar 3590, Corning, NY, USA) and a commercial kit (Human IgA ELISA Quantification set, E80-102, Bethyl laboratories, Montgomery, USA), in duplicate, according to the manufacturer's instructions. After coating with primary antibody and blocking the plates, saliva samples were diluted at 1:1,000 and incubated for one hour at room temperature. After washing, the plates were incubated with anti-lgA peroxidase conjugated antibody. To determine salivary SIgA concentration $(\mu \mathrm{g} / \mathrm{ml})$, absorbance values at $450 \mathrm{~nm}$ were plotted against the standard curve obtained for the serial dilutions of a known concentration of purified human IgA. The salivary SIgA secretion rate was expressed as the quantity of SIgA secreted per minute ( $\mu \mathrm{g} / \mathrm{min})$.

\section{Statistical Analysis}

Normal distribution was assessed using the Shapiro-Wilk test. Variations in each measured DES subscale score and salivary SIgA among different years were analyzed using the ANOVA and Tukey's post hoc test and Kruskal-Wallis and Dunn's post hoc tests. Differences between male and female variables were assessed with the Student t test or Mann-Whitney $U$ test. The frequency of males and females in different years was assessed using the chi-squared test. Spearman's correlation coefficient was used to identify the correlation between stress and measurements in saliva. The statistical significance level for all analysis was $\mathrm{P}<0.05$. (GraphPad Prism v. 6.07)

\section{RESULTS}

Of the 289 students regularly enrolled on the course, 82 (28.3\%) were excluded from the sample: 39 (13.5\%) did not match the inclusion criteria; $25(8.6 \%)$ refused to participate; and 18 $(6.2 \%)$ were absent on the day of data collection. Thus the final sample comprised 207 (71.63\%) students, recruited from the first to fifth years, median age 21.5 ( 25 to $75 \%$ interquartile: 20.1 - 23.1) years, 152 (73.4\%) females.

Age, salivary measurements and the sum of DES scores are presented in Table 1 . Post-hoc power analysis was performed considering SIgA concentration as the primary outcome and SIgA secretion rate as secondary outcome, and it was powered to detect a significant difference with a $90 \%$ minimum power (Correlation: $\alpha=0.05$; effect size $=0.360$; sample size 207). There was no difference in age between men and women. Salivary flow rate, SIgA concentration and secretion rate were higher in males $(P<0.05)$. However, the sum of DES scores was higher in females. The frequency of females was not significantly different among the different years of study $(X 2=4.25, P=0.37)$.

The second, third and fifth year students presented increased perceived stress scores compared to the first year students (Figure 1a). The female students presented increased stress scores in the second, third and fifth years in relation to the first year female students (Figure 1b). The male students did not present significant differences in stress scores among the different years (Figure 1c). The most important sources of perceived stress were 'Examinations and grades' and 'Fear of failing course or year' considered as very stressful by $56.5 \%$ and $55.2 \%$ of dental students, respectively.

Salivary flow rate was significantly decreased in the second, third and fifth year students in relation to the first year students (Figure 2). SIgA concentration was higher among the fourth year students. However, the second, third and fifth year students presented decreased levels of SIgA secretion rate of antibodies in relation to the fourth year students (Figure 2 ).

Table 1. Age, salivary flow rate, SIgA concentration and secretion rate, and sum of DES scores.

\begin{tabular}{|c|c|c|c|c|}
\hline Variable & $\begin{array}{r}\text { Total } \\
\mathrm{n}=207(100.0 \%)\end{array}$ & $\begin{array}{r}\text { Female } \\
n=152(73.4 \%)\end{array}$ & $\begin{array}{r}\text { Male } \\
n=55(26.6 \%)\end{array}$ & $\mathbf{P}$ \\
\hline Age (years)* & $21.5(20.1-23.1)$ & $21.5(20.1-22.9)$ & $21.4(20.3-23.3)$ & 0.54 \\
\hline Salivary flow rate $(\mathrm{ml} . \mathrm{min}-1)^{*}$ & $0.55(0.40-1.00)$ & $0.55(0.35-0.90)$ & $0.65(0.45-1.00)$ & 0.03 \\
\hline SIgA Concentration ( $\mu \mathrm{g} \cdot \mathrm{ml}-1$ ) & $215.35 \pm 192.45$ & $195.55 \pm 184.49$ & $270.07 \pm 204.85$ & 0.01 \\
\hline SIgA secretion rate ( $\mu$ g.min- 1 )* & $87.76(28.27-182.14)$ & $67.38(23.10-159.04)$ & $126.38(64.11-268.48)$ & 0.001 \\
\hline DES & $76.24 \pm 17.51$ & $78.97 \pm 16.42$ & $68.70 \pm 18.36$ & 0.000 \\
\hline
\end{tabular}

* Variables expressed in median and interquartile ranges (25 a 75\%). p values are obtained using Mann-Whitney test for differences $(\alpha<0.05)$. 
Figura 1. Mean (standard deviation) DES scores of dental students. ${ }^{*} \mathrm{P}<0.05, * * * \mathrm{P}<0.005$ in relation to first year students, ANOVA and Tukey's tests
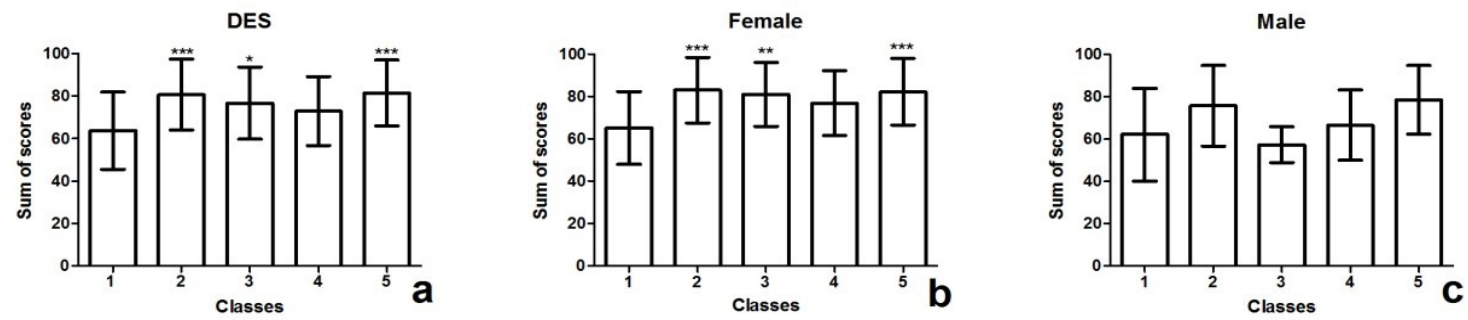

Figura 2. Median levels of saliva flow rate, total concentration of salivary SIgA and secretion rate of salivary SIgA. * $\mathrm{P}<0.05, * * *$ $\mathrm{P}<0.005$ in relation to first year students (Dunn's Test). \# $\mathrm{P}<0.05$, \#\# $\mathrm{P}<0.01$ in relation to fourth year students (Dunn's test)
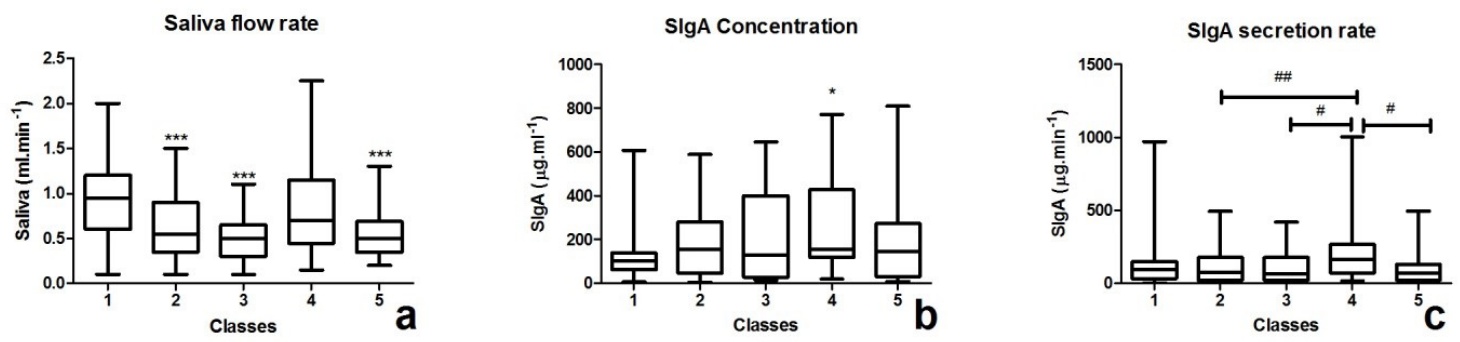

No correlation was found between the sum of DES scores and salivary flow rate, SIgA concentration or secretion rate were found (Table 2). Salivary parameters were not correlated with DES scores in men or women (Table 2).

It is possible to note in the Table 3 that a moderate inverse relationship was observed between the subscale Academic Performance and SIgA secretion rates among 2 nd year students. Similar relationships were also detected between SIgA secretion rates and the subscales Interpersonal Relationships (3rd year students), Difficulties and Insecurities about Professional Future ( $4^{\text {th }}$ year students).

Table 2. Spearman correlation test between salivary parameters and DES score.

\begin{tabular}{lrrr}
\hline & Salivary flow rate & SIgA concentration & $\begin{array}{r}\text { SIgA secretion rate } \\
\mathbf{r}(\mathbf{P})\end{array}$ \\
\hline DES & $\mathbf{r}(\mathbf{P})$ & $-0.13(0.07)$ & $-0.12(0.08)$ \\
DES female & $-0.008(0.89)$ & $-0.11(0.14)$ & $-0.26(0.20)$ \\
DES male & $-0.08(0.31)$ & $0.01(0.99)$ & $-0.07(0.53)$ \\
\hline
\end{tabular}

Table 3. Significant correlations (Spearman correlation test) between salivary measurements and DES subscales ( $\alpha<0.05)$.

\begin{tabular}{|c|c|c|c|}
\hline DES subscale* & $\begin{array}{r}\text { Salivary flow rate } \\
r(P)\end{array}$ & $\begin{array}{r}\text { SIgA concentration } \\
r(P)\end{array}$ & $\begin{array}{r}\text { SIgA secretion rate } \\
r(P)\end{array}$ \\
\hline \multicolumn{4}{|c|}{ Academic Performance } \\
\hline 2nd & $-0.07(0.59)$ & $-0.29(0.04)$ & $-0.33(0.01)$ \\
\hline 5th & $0.32(0.04)$ & $-0.16(0.31)$ & $-0.007(0.96)$ \\
\hline \multicolumn{4}{|c|}{ Difficulties and Insecurities about Professional Future } \\
\hline 4th & $0.14(0.37)$ & $-0.36(0.02)$ & $-0.30(0.05)$ \\
\hline \multicolumn{4}{|c|}{ Individual and Institutional Factors } \\
\hline 2 nd & $0.28(0.04)$ & $-0.16(0.25)$ & $0.09(0.52)$ \\
\hline \multicolumn{4}{|l|}{ 4th } \\
\hline \multicolumn{4}{|c|}{ Interpersonal relationships } \\
\hline $3 r d$ & $0.24(0.10)$ & $0.24(0.10)$ & $-0.32(0.02)$ \\
\hline
\end{tabular}


Individual items of DES did not impact on salivary flow rate. A weak correlation was found between SIgA concentration with Amount of assigned classwork $(P=0.10)$, Lack of confidence in self to be a successful dentist $(P=0.05)$, Lack of time for relaxation $(P=0.86)$, Financial responsibilities $(P=0.07)$, and Personal physical health $(P=0.10)$. A weak correlation was also found between SIgA secretion rate with DES items Lack of cooperation by patient in their home care $(P=0.003)$, Patients being late or not showing up for their appointments $(P=0.02)$, Lack of confidence in self to be a successful dentist $(P=0.008)$, Lack of time for relaxation ( $P=0.001)$, Amount of cheating in dental school $(P=0.02)$, Lack of time to do assigned school work $(P=0.003)$, and personal physical health $(P=0.019)$, (Table 4).

Table 4. Significant Spearman correlations between saliva measurement and DES items

\section{Salivary flow rate SIgA concentration SIgA secretion rate}

$r(P) \quad r(P) \quad r(P)$

\begin{tabular}{|c|c|c|c|}
\hline Amount of assigned classwork & $-0.11(0.10)$ & $-0.16(0.02)$ & $0.04(0.55)$ \\
\hline Lack of cooperation by patients in their home care & $-0.05(0.43)$ & $0.03(0.64)$ & $-0.20(0.003)$ \\
\hline Patients being late or not showing up for their appointments & $-0.06(0.38)$ & $0.04(0.52)$ & $-0.15(0.02)$ \\
\hline Lack of time for relaxation & $-0.01(0.86)$ & $-0.16(0.01)$ & $-0.22(0.001)$ \\
\hline Amount of cheating in dental school & $-0.12(0.07)$ & $-0.02(0.72)$ & $-0.16(0.02)$ \\
\hline Lack of time to do assigned school work & $-0.02(0.75)$ & $-0.02(0.68)$ & $-0.20(0.003)$ \\
\hline Personal physical health & $0.11(0.10)$ & $-0.20(0.005)$ & $-0.19(0.019)$ \\
\hline
\end{tabular}

Spearman correlation test $(\alpha<0.05)$

\section{DISCUSSION}

This study presents new data on oral immune functioning of dental students and self-reported measures of stress among undergraduate dental students. It demonstrates the relationship between some aspects of self-perceived stress with salivary secretion and SIgA levels in Brazilian dental students; some stressors on the DES questionnaire might impact on salivary secretory immunity. No relationship was found between the overall DES scores and salivary flow, SIgA concentration or secretion rate. Other studies have also detected no correlation between self-perceived stress scores and salivary biomarkers suggesting that a question used to indicate self-perceived stress may be too simplistic a measure to assess the relationship between stress and salivary levels of antibodies ${ }^{13,28}$. Differences in perception of stress between male and female students were also observed.

Male subjects presented increased salivary flow rate, SIgA concentration and secretion rate, but decreased DES scores, in relation to female students. As saliva secretion is under neuroendocrine control, we supposed that it may be influenced by psychological stress and be inversely correlated to DES scores. However, we did not find this correlation, suggesting that there are gender-related differences in saliva secretory function that were not correlated with DES scores. Gender differences in salivary secretion may be associated with stimulation of gonadal steroid hormones and autonomic nervous system regulation of salivary glands ${ }^{29-32}$. Estrogen seems to upregulate salivary secretion and secretory immunity, ${ }^{30,32}$ although morphological differences between male and female salivary glands may also account for the differences in volume of secreted saliva. Saliva secretion is also upregulated by parasympathetic autonomic nervous stimulation ${ }^{33,34}$. On the other hand, mental stress can influence salivary secretion, decreasing the saliva flow rate ${ }^{15}$. Indeed, mental stress can upregulate sympathetic activity to a higher magnitude in women than men, ${ }^{33,35}$ resulting in altered secretory function of the salivary glands (i.e., low saliva flow rate and IgA secretion) ${ }^{2,36}$. Although low secretory function and increased DES scores were found in female students, no significant correlations between the sum of DES scores and salivary parameters were detected. No relationship was found between the overall DES scores and salivary flow, SIgA concentration or secretion rate. These results are consistent with other studies ${ }^{13,28}$.

Other studies have also reported that female dental students demonstrated higher stress rates compared to males ${ }^{5,37}$. Nevertheless, $\mathrm{Ng}$ et al.7 did not find gender differences in stress levels in Singaporean dental students, although women demonstrated greater insecurity regarding their professional future. They also find out that DES scores presented a low inverse correlation with SIgA levels in male and female Singaporean dental students ${ }^{7}$. Polychronopoulou and Divaris reported that females generally reported higher perceived stress in some aspects of the educational process, especially those related to insecurity ${ }^{5}$. Although the present study agreed with those who reported increased perceived stress in females, ${ }^{5,37}$ and stress may decrease salivary secretory function, ${ }^{2,36}$ our results suggest that overall stress and gender differences detected by DES were not associated with levels of salivary SIgA. Nevertheless, some specific aspects of student stress may negatively impact on SIgA 
secretion.

A strong side of the study is that the DES items were grouped into five subscales by means of factorial analysis, which is an important tool for ascertaining psychometric indicators. Factorial analysis allows identification of how the items are organized in subscales according to the samples' constructs instead of being theoretically divided. The stressful potential of the subscale Academic Performance is well documented, with the item "Examinations and Grades" being frequently perceived as the most stressful ${ }^{38-40}$. An inverse relationship was detected between this subscale and SIgA concentration and secretion rate among 2 nd year students, which corroborates previous findings ${ }^{7}$. On the other hand, although the item "Examinations and Grades" was the highest scored among all the students, a correlation was not identified with salivary parameters. Some papers have identified a positive, ${ }^{15,16,22}$ and others a negative ${ }^{13,23}$ relationship between exams (an acute stressor) and salivary SIgA. Due to the curriculum characteristics, the studied population is subjected to different types of examinations that can influence the student's perception of stress related to the topic. The examinations may be considered an acute stressor16 that was not experienced in the weeks when the present study was performed (beginning of the second semester).

Subjective reports of acute and chronic stress may impact on secretory immunity in different ways. A study that investigated undergraduate students observed that an acute psychological stressor, such as a job interview, could impair secretion of salivary SIgA during recovery after the interview ${ }^{2}$. Another study in nursing students revealed that increased levels of SIgA were detected immediately after an examination but were significantly decreased after two hours.16 It was also demonstrated that among medical students final exams periods evoked reduced salivary flow rate, independent of psychological stress $^{15}$. The authors also demonstrated that psychological stress increased salivary secretion of antibodies in medical students ${ }^{15}$. A study in undergraduate students investigating SIgA levels in examination periods demonstrated increased levels of SIgA levels immediately after the exams, which were associated with the student performance in the exams ${ }^{22}$.

In the present study it was observed that salivary SIgA concentration was higher in students enrolled in the fourth year, and these same students presented a higher secretion rate, compared to students in the second, third and fifth years. It has already been reported that salivary IgA secretion rate was inversely correlated with the self-perceived stress level ${ }^{7}$ and that variations in salivary SIgA may be sensitive to the intensity of the stressor ${ }^{13}$. The SIgA levels also did not alter among undergraduate American students over an extended period, although these levels might have been altered in response to acute analysis of stress in this group ${ }^{23}$.

In a meta-analysis published in 2004, Segerstrom and Miller concluded that stressful events did not produce a strong pattern of immune changes if considered in total. Brief stressors were associated with adaptive upregulation of some parameters of natural immunity, such as humoral immunity, and downregulation of some functions of specific immunity, such as cellular immunity. Chronic stressors were related to suppression of both cellular and humoral processes ${ }^{41}$. According to this reasoning, immune response alterations would be best observed in longitudinal studies.

A weak correlation was observed between SIgA concentration and "Amount of assigned classwork", "Lack of confidence in self to be a successful dentist", "Lack of time for relaxation", "Financial responsibilities", "Personal physical health". A weak correlation was also observed between SIgA secretion rate and DES scores in: "Patients being late or not showing for their appointments", "Lack of confidence in self to be a successful dentist", "Lack of time for relaxation", "Lack of time to do assigned school work", "Amount of cheating in dental school", "Lack of cooperation by patient in their home care", and "Personal physical health". These items are also more prevalent in studies on stress levels in undergraduates, ${ }^{5,37}$ proving to be a significant stressor among dental students. Among the final year students the subscale Difficulties and Insecurities about Professional Future, the item "Lack of confidence in self to be a successful dentist", significantly correlated to SIgA secretion. This reaffirms previous findings that revealed that fifth-year students face anxieties about the future and may be uncertain about some features of their dental education ${ }^{10,42-44}$.

\section{CONCLUSION}

We have observed that the large workload and tasks related to dental school, added to the insecurity of the undergraduates who took part in this survey were the major sources of stress in these dental students. No correlation between the sum of DES scores and saliva flow rate, SIgA concentration or secretion rate were found, although a correlation was observed with some stressors listed in the DES. Programs for managing these stressors among undergraduate dental students are not yet a reality in Brazilian universities, but could help in the management of strain and contribute to the control of the immune functions of the students.

\section{REFERENCES}

1. Lester SR, Brown JR, Aycock JE, Grubbs SL, Johnson RB. Use of saliva for assessment of stress and its effect on the immune system prior to gross anatomy practical examinations. Anatl Sci Educ. 2010 Jul-Ago; 3(4):160-167. doi: 10.1002/ase.161.

2. Campisi J, Bravo Y, Cole J, Gobeil K. Acute psychosocial stress differentially influences salivary endocrine and immune measures in undergraduate students. Physiol Behav. 2012 Oct 10; 107(3):317-321. doi: 10.1016/j. physbeh.2012.09.003.

3. Sanders AE, Lushington K. Effect of perceived stress on student performance in dental school. J Dent Educ. 2002 Jan; 66(1):75-81. PubMed PMID: 12358103.

4. Naidu RS, Adams JS, Simeon D, Persad S. Sources of stress and psychological 
disturbance among dental students in the West Indies. J. Dent Educ. 2002 Sep;66(9):1021-1030. PubMed PMID: 12374261.

5. Polychronopoulou A, Divaris K. Perceived sources of stress among Greek dental students. J. Dent Educ. 2005Jun; 69(6):687-692. PubMed PMID 15947215.

6. Elani HW, Allison PJ, Kumar RA, Mancini L, Lambrou A, Bedos C. A systematic review of stress in dental students. J. Dent Educ. 2014Feb; 78(2):226-242. PubMed PMID: 24489030.

7. Ng V, Koh D, Mok B, Lim LP, Yang Y, Chia SE. Stressful life events of dental students and salivary immunoglobulin A. Int J Immunopathology Pharmacol.2004 May-Aug;17(2 Suppl):49-56.

8. Bathla $M$, Singh $M$, Kulhara $P$, Chandna $S$, Aneja J. Evaluation of anxiety, depression and suicidal intent in undergraduate dental students: A crosssectional study. Contemp Clin Dent. 2015 Apr-Jun; 6(2):215-222. doi: 10.4103/0976-237X.156050.

9. Polychronopoulou A, Divaris K. Dental students' perceived sources of stress: a multi-country study. J Dent Educ.2009 May;73(5):631-639. PubMed PMID: 19433538

10. Kumar S, Dagli RJ, Mathur A, Jain M, Prabu D, Kulkarni S. Perceived sources of stress amongst Indian dental students. Eur J Dent Educ. 2009 Feb; 13(1):3945. doi: 10.1111/j.1600-0579.2008.00535.x.

11. Heath JR, Macfarlane TV, Umar MS. Perceived sources of stress in dental students. Dent update. Apr 1999; 26(3): 94-98.

12. Humphris G, Blinkhorn A, Freeman R, Gorter R, Hoad-Reddick G, Murtomaa $\mathrm{H}$, et al. Psychological stress in undergraduate dental students: baseline results from seven European dental schools. Eur J Dent Educ. 2002 Feb; 6(1):22-29. PubMed PMID: 11872070.

13. Ng V, Koh D, Mok BY, Chia SE, Lim LP. Salivary biomarkers associated with academic assessment stress among dental undergraduates. J Dent Educ. Oct 2003;67(10):1091-1094. PubMed PMID: 14587673.

14. Bellussi L, Cambi J, Passali D. Functional maturation of nasal mucosa: role of secretory immunoglobulin A (SIgA). Multidiscip Respir Med. 2013;8(1):46.

15. Matos-Gomes N, Katsurayama M, Makimoto FH, Santana LL, ParedesGarcia E, Becker MA, et al. Psychological stress and its influence on salivary flow rate, total protein concentration and IgA, IgG and IgM titers. Neuroimmunomodulation. 2010;17(6):396-404.

16. Takatsuji K, Sugimoto $\mathrm{Y}$, Ishizaki S, Ozaki Y, Matsuyama E, Yamaguchi Y. The effects of examination stress on salivary cortisol, immunoglobulin $A$, and chromogranin A in nursing students. Biomed Res. 2008 Aug; 29(4):221-224. PubMed PMID: 18724010.

17. Phillips AC, Carroll D, Evans P, Bosch JA, Clow A, Hucklebridge F, et al. Stressfu life events are associated with low secretion rates of immunoglobulin $A$ in saliva in the middle aged and elderly. Brain Behav Immun. 2006 Mar; 20(2):191-197. doi: 10.1016/j.bbi.2005.06.006

18. Hucklebridge $F$, Clow A, Evans P. The relationship between salivary secretory immunoglobulin A and cortisol: neuroendocrine response to awakening and the diurnal cycle. Int J Psychophysiol. 1998 Dec; 31(1):69-76.

19. Mann SL, Selby EA, Bates ME, Contrada RJ. Integrating affective and cognitive correlates of heart rate variability: a structural equation modeling approach. Int J Psychophysiology. 2015 Oct; 98(1):76-86.

20. Proctor GB, Carpenter GH, Anderson LC, Garrett JR. Nerve-evoked secretion of immunoglobulin $A$ in relation to other proteins by parotid glands in anaesthetized rat. Exp Physiol. 2000Sep; 85(5):511-518. PubMed PMID: 11038402.

21. Shapiro SL, Shapiro DE, Schwartz GE. Stress management in medical education: a review of the literature. Acad Med. $2000 \mathrm{Jul}$; 75(7):748-759. PMID:
10926029.

22. Sarid O, Anson O, Yaari A, Margalith M. Academic stress, immunological reaction, and academic performance among students of nursing and physiotherapy. Res Nurs Health. 2004 Oct; 27(5): 370-377.

23. Murphy L, Denis R, Ward CP, Tartar JL. Academic stress differentially influences perceived stress, salivary cortisol, and immunoglobulin-A in undergraduate students. Stress. 2010 Jul;13(4):365-370. doi: 10.3109/10253891003615473.

24. Alzahem AM, Van der Molen HT, Alaujan AH, De Boer BJ. Stress management in dental students: a systematic review. Adv Med Educ Pract. 2014; 5:167-176. doi: 10.2147/AMEP.S46211. PubMed Central PMCID: PMV4041220.

25. Garbee WH, Jr., Zucker SB, Selby GR. Perceived sources of stress among dental students. J Am Dent Assoc. . 1980; Jun 100(6): 853-857. PubMed PMID: 6929835.

26. Sangiorgio JPM. Estresse em odontologia: adaptação transcultural e validação do Dental Environmental Stress para estudantes de odontologia brasileiros. [dissertation]. Londrina PR): University of Londrina; 2013.

27. Brasil. Ministério da Educação. Conselho Nacional de Educação. Câmara de Educação Superior. Resolução CNE/CES 1.300/2001 de 06 de novembro de 2001. Diretrizes curriculares nacionais dos cursos de graduação em farmácia e odontologia. Diário Oficial [da] República Federativa do Brasil. 2001 Dez 7; Seção 1, p. 25.

28. Wawrzyniak AJ, Whiteman MCP. Perceived stress, loneliness, and interaction with fellow students does not affect innate mucosal immunigy in first year university students. Japanese Psychological Research. 2011 May; 53(2):121132. doi: 10.1111/j.1468-5884.2011.00466.x.

29. Proctor GB, Carpenter GH. Salivary secretion: mechanism and neural regulation. Monogr Oral Sci. 2014; 24: 14-29. doi: 10.1159/000358781.

30. Proctor GB, Carpenter GH. Regulation of salivary gland function by autonomic nerves. Auton Neurosci. . 2007Apr 30; 133(1):3-18. doi: 10.1016/j. autneu.2006.10.006

31. Van Anders SM. Gonadal steroids and salivary IgA in healthy young women and men. Am J Hum Biol. 2010May-Jun; 22(3):348-352. doi: 10.1002/ ajhb. 20997.

32. Tsinti M, Kassi E, Korkolopoulou P, Kapsogeorgou E, Moutsatsou P, Patsouris $E$, et al. Functional estrogen receptors alpha and beta are expressed in normal human salivary gland epithelium and apparently mediate immunomodulatory effects. Eur J Oral Sci. . Oct 2009;117(5):498-505.

33. Alvares GA, Quintana DS, Kemp AH, Van Zwieten A, Balleine BW, Hickie IB, et al. Reduced heart rate variability in social anxiety disorder: associations with gender and symptom severity. PLoS One. 2013 Jul; 8(7):e70468. doi: 10.1371/ journal.pone.0070468

34. Bosch JA, de Geus EJ, Veerman EC, Hoogstraten J, Nieuw Amerongen AV. Innate secretory immunity in response to laboratory stressors that evoke distinct patterns of cardiac autonomic activity. Psychosom Med. 2003 Mar-Apr; 65(2):245-258

35. Yang H, Drummer TD, Carter JR. Sex differences in sympathetic neural and limb vascular reactivity to mental stress in humans. Am J Physiol Heart Circ Physiol. 2012; 304(3):H436-H443. doi: 10.1152/ajpheart.00688.2012.

36. Nagy $T$, van Lien R, Willemsen $G$, Proctor $G$, Efting $M$, Fülöp $M$, et al. A fluid response: Alpha-amylase reactions to acute laboratory stress are related to sample timing and saliva flow rate. Biol Psychol. 2015 Jul;109:111-119. doi: 10.1016/j.biopsycho.2015.04.012.

37. Abu-Ghazaleh SB, Rajab LD, Sonbol HN. Psychological stress among dental students at the University of Jordan. J Dent Educ. 2011 Aug;75(8):1107-1114. PubMed PMID: 21828305.

38. Fonseca J, Divaris K, Villalba S, Pizarro S, Fernandez M, Codjambassis A, et al. 
Perceived sources of stress amongst Chilean and Argentinean dental students. Eur J Dent Educ. 2013 Feb;17(1):30-38. doi: 10.1111/eje.12004.

39. Elani HW, Bedos C, Allison PJ. Sources of stress in Canadian dental students: a prospective mixed methods study. J Dent Educ. 2013 Nov; 77(11):1488-1497. PubMed PMID: 24192414.

40. Alzahem AM, Van der Molen HT, De Boer BJ. Effect of year of study on stress levels in male undergraduate dental students. Adv Med Educ Pract. 2013;4:217222

41. Segerstrom SC, Miller GE. Psychological stress and the human immune system: a meta-analytic study of 30 years of inquiry. Psychol Bull. 2004 Jul;130(4):601-630. doi: 10.1037/0033-2909.130.4.601.

42. Morse Z, Dravo U. Stress levels of dental students at the Fiji School of Medicine. Eur J Dent Educ. 2007 May; 11(2):99-103.

43. Divaris K, Polychronopoulou A, Villa Torres L, Mafla AC, Moya GA, GonzálezMartínez $F$, et al. Extracurricular factors influence perceived stress in a large cohort of Colombian dental students. J Dent Educ. 2014;78(2):213.

44. Acharya S. Factors affecting stress among Indian dental students. J Dent Educ. 2003 Oct; 67(10):1140-1148. PubMed PMID: 14587679. 